Images in...

\title{
Pandora's box: a threatening foreign body
}

\author{
Eleonora Giorgini, Salomone Di Saverio, Andrea Biscardi, Silvia Villani, Nicola Clemente, \\ Nicola Antonacci, Gregorio Tugnoli
}

Emergency and Trauma Surgery Unit (Head Prof. G. Tugnoli), Maggiore Hospital Trauma Center, Bologna, Italy

Correspondence to Salomone Di Saverio, salo75@inwind.it

\section{DESCRIPTION}

A 38-year-old man, a prisoner at a district jail, was brought to the accident and emergency department complaining of gastric pain accompanied by nausea but without vomiting. He had no fever and his vital parameters were normal.

Blood testing, including full blood count, $\mathrm{C}$ reactive protein, liver function tests and cardiac enzymes were unremarkable. Examination revealed a firm mass, palpable at the level of the mesogastrium in an otherwise soft and non-tender abdomen. The patient related passing no flatus or stools in the previous $24 \mathrm{~h}$.

On rectal examination, a solid foreign body was felt. Pushing that body transmitted an impulse palpable in the mesogastrium. At this point, the patient revealed to have privately inserted a foreign body into the rectum few hours earlier.
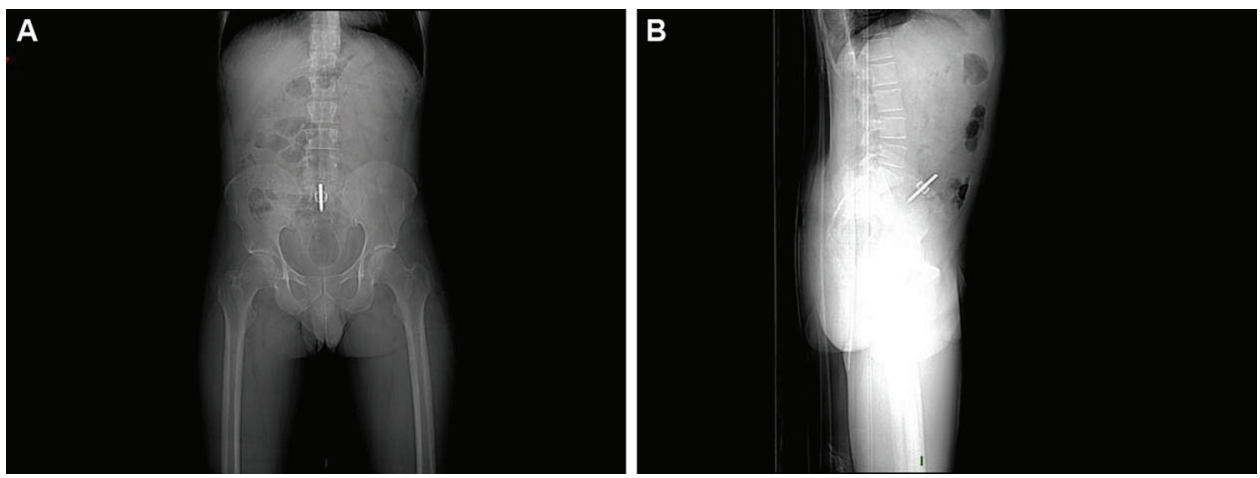

Figure 1 Plain abdominal x-ray showing the rectal body. The size of the foreign body seems small and the object seems sharp.
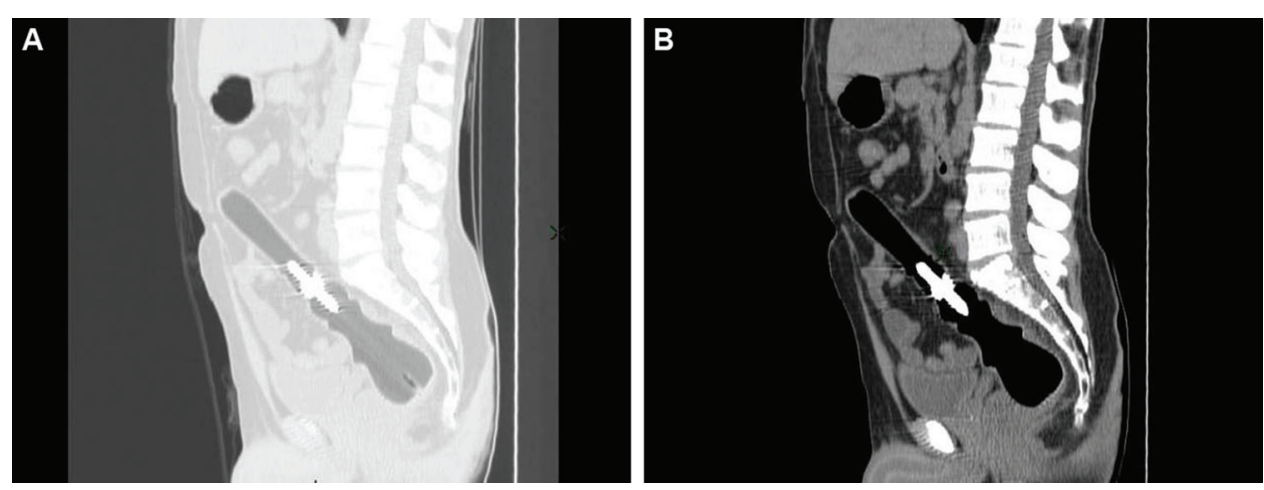

Figure 2 Multiplanar-reformation CT scan demonstrating the real size (over $20 \mathrm{~cm}$ in length) of the rectal foreign body, extending upwards and reaching the mesogastrium and left hypochondrium.
This prompted an immediate CT scan of the abdomen. The whole sigmoid colon, from the rectum up to the descending colon, was stretched by a peppermill-shaped object. Neither intra-abdominal free air nor free fluid was present (figures 1-3).

The patient was taken to the theatre and under general anaesthesia, the foreign body (figure 4) was manually extracted, avoiding a midnight laparotomy. A psychiatric and psychosocial assessment was provided, following the patient's request, the next day.

'Self-injurious' behaviour is a fairly common phenomenon in prisoners, but most reports are found in the surgi$\mathrm{cal}$ and gastroenterological literature. They tend to focus on complication rates and surgical techniques for removing the object. More prospective studies of the subset of individuals who exhibit self-injurious behaviour will help 


\section{BMJ Case Reports}
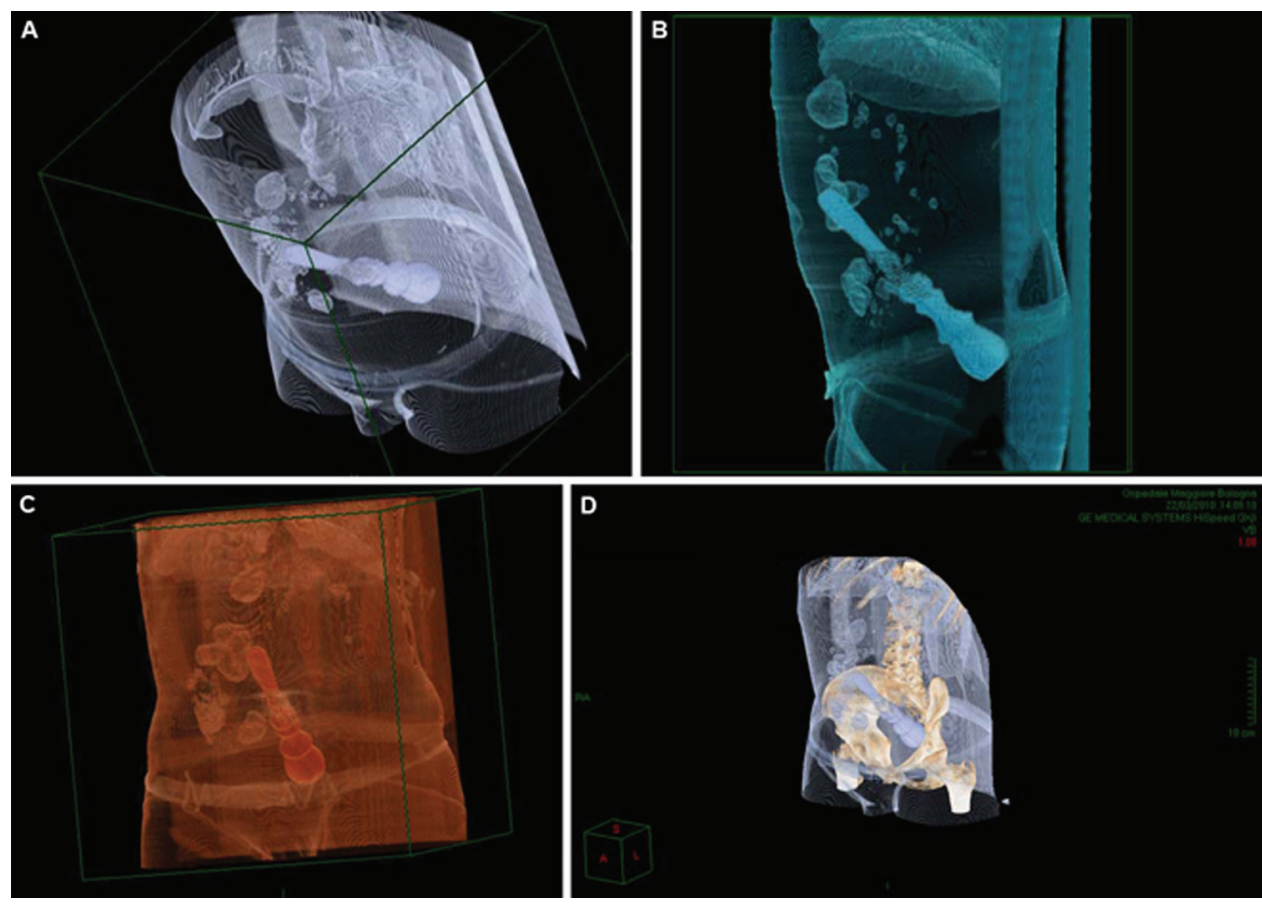

Figure 3 Three-dimensional reconstruction CT scan showing the actual size, location, direction and extent of the foreign body inside the abdominal cavity as well as the relationship with surrounding structures.

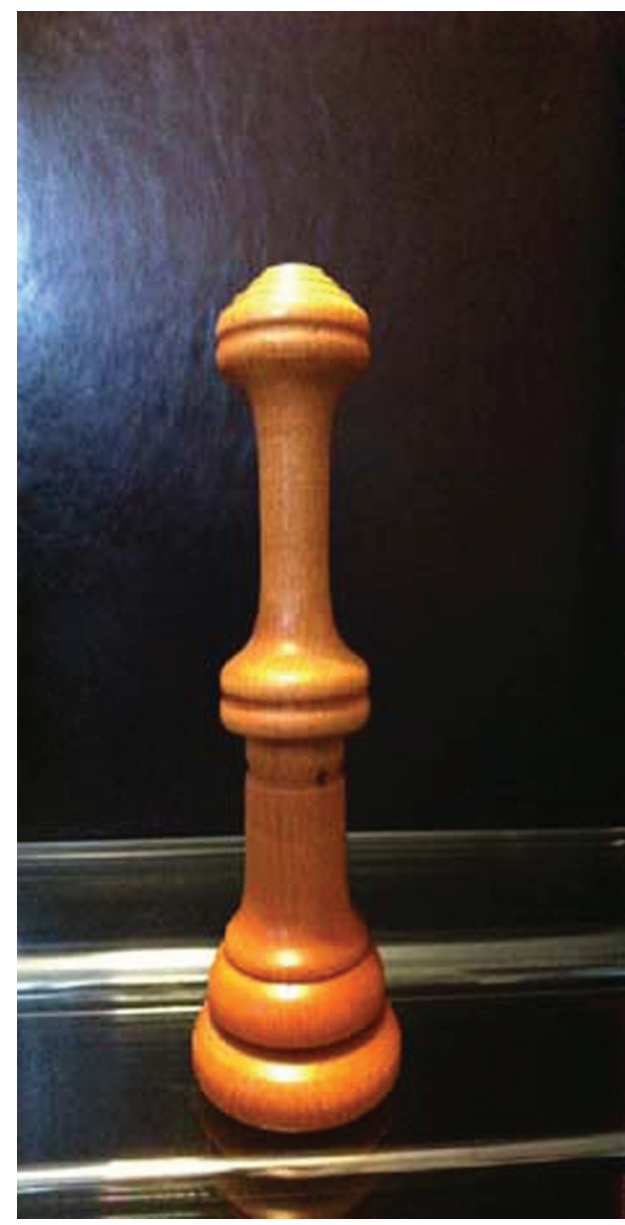

in the development of appropriate treatment and management approaches. ${ }^{1}$

The emergency room physician must confirm the presence of rectal foreign body. Extraction in an emergency room setting is usually impossible and patients with persistent rectal foreign bodies should be referred to a colorectal surgeon. ${ }^{2}$ Rectal foreign bodies are amenable to transanal extraction. Those located in the sigmoid colon more often require repair of perforated bowel or retrieval via a colotomy. ${ }^{3}$

Competing interests None.

Patient consent Obtained

\section{REFERENCES}

1. Gitlin DF, Caplan JP, Rogers MP, et al. Foreign-body ingestion in patients with personality disorders. Psychosomatics 2007:48:162-6.

2. Goldberg JE, Steele SR. Rectal foreign bodies. Surg Clin North Am 2010;90:173-84.

3. Lake JP, Essani R, Petrone P, et al. Management of retained colorectal foreign bodies: predictors of operative intervention. Dis Colon Rectum 2004;47:1694-8.

Figure 4 Foreign body. 


\section{BMJ Case Reports}

This pdf has been created automatically from the final edited text and images.

Copyright 2011 BMJ Publishing Group. All rights reserved. For permission to reuse any of this content visit http://group.bmj.com/group/rights-licensing/permissions.

BMJ Case Report Fellows may re-use this article for personal use and teaching without any further permission.

Please cite this article as follows (you will need to access the article online to obtain the date of publication).

Giorgini E, Saverio SD, Biscardi A, Villani S, Clemente N, Antonacci N, Tugnoli G. Pandora's box: a threatening foreign body. BMJ Case Reports 2011;

10.1136/bcr.06.2010.3110, date of publication

Become a Fellow of BMJ Case Reports today and you can:

- Submit as many cases as you like

- Enjoy fast sympathetic peer review and rapid publication of accepted articles

- Access all the published articles

Re-use any of the published material for personal use and teaching without further permission

For information on Institutional Fellowships contact consortiasales@bmjgroup.com

Visit casereports.bmj.com for more articles like this and to become a Fellow 